\title{
MONITORING OF INDOOR ENVIRONMENTAL CONDITIONS OF THE KVERNES (NORWAY) STAVE CHURCH
}

\section{CHIARA BERTOLIN ${ }^{*}$, LAVINIA DE FERRI ${ }^{1}$, TONE MARIE OLSTAD ${ }^{2}$}

\author{
${ }^{1}$ Department of Mechanical and Industrial Engineering, Norwegian University of Science and \\ Technology, Trondheim, Norway. \\ e-mail: chiara.bertolin@ntnu.no, https://www.ntnu.edu/employees/chiara.bertolin (*corresponding \\ author); lavinia.de.ferri@ntnu.no \\ ${ }^{2}$ Norsk institutt for kulturminneforskning, Storgata 2, 0155 Oslo, Norway \\ e-mail: tone.olstad@niku.no; web page: https://www.niku.no/en/ansatt/tone-marie-olstad/
}

Keywords: Risk assessment, Stave churches, wood, indoor monitoring

\begin{abstract}
.
The proposed study deals with environmental data collected in the Kvernes stave church, belonging to the Møre type. The nave and the chancel belonging to the original structure, probably dated back to early 1600, are one of the few cases - among the 28 existing Stave Churches - still maintaining the internal wall painting, realized with a tempera technique in 1633. Due to its geographical position, the Kvernes church is particularly exposed to weather and consequently maintenance interventions have been carried out in 2015 (Stave Church Preservation Programme) to preserve the building. Previously in 2011 and 2012, 4 data loggers were installed to monitor indoor microclimatic variations basically referable to climatic external conditions, the performance of liturgical functions, and to the presence of visitors (depending on the periods of the year), since none active heating system has never been installed in the church.

In the frame of the international research project SyMBoL (Sustainable Management of Heritage Buildings in a Long-term perspective) such environmental data were elaborated. They represent the firsts internationally published information from long-term monitoring campaigns in stave churches.
\end{abstract}

\section{INTRODUCTION}

The monitoring of internal conditions of historical buildings is an issue receiving growing attention in the last decades even if not everywhere. Data from long- and short-term indoor monitoring campaigns are still not easily available for the northern Europe Cultural Heritage, particularly rich in stone-based monuments or in peculiar wooden-based structures of Medieval epoch such as most of the Stave Churches. Most of existing data are still unpublished at international level, being generally part of internal reports created by the Norwegian Directorate of Cultural Heritage (Riksantikvaren) [1], and conservation reports by the Norwegian Institute for Cultural Heritage Research (NIKU). Exceptions are represented by few papers as BylundMelins thesis from 2017, an important contribution to the correlation between climatic stress and painted wood [2], and the recent contribution of Napp et al. [3] studying a stone-based medieval church in Sweden and assessing an adaptive ventilation system for reducing internal 
Relative Humidity (RH) conditions. Alternatively, only a couple of other scientific articles discuss such problem, focusing on wooden architectural heritage. In 1994 Olstad reports about the results of a project started in 1986 with the aim of improving the conditions for painted wooden objects in wooden churches in Norway and involving the recording of Temperature $(\mathrm{T})$ and RH values in two unheated and three heated churches [4]. About 18 years later, in 2012, relative humidity variations induced by the heating system were studied in the Hedalen Stave church by Lasyk et al. [5]: in that case internal temperature was continuously maintained at $7^{\circ} \mathrm{C}$ and increased up to $18-19^{\circ} \mathrm{C}$ when the church was used. As the authors report, the heating episodes lead to periodic fluctuations of RH and they refer to data of monitoring campaigns acquired in three main intervals: from 1986 to 1994, from 2001 to 2003 and from 2008 to 2009. The maximum fluctuation ( $38 \%$ in 36 h) was found for winter $2008 / 2009$, whereas absolute minimum and maximum reached values were 21 and $72 \%$ respectively [5]. Very recently a paper mainly focusing on alteration products observed on the Hopperstad stave church also reported average $\mathrm{T}$ and $\mathrm{PH}$ data recorded from December to June 2017 [6].

Efforts are currently ongoing to fill this gap thanks to active programs such as the SyMBoL (Sustainable Management of heritage Buildings in a Long-term perspective) coordinated by the Norwegian University of Science and Technology (NTNU), and the MOV Projects coordinated by NIKU. The first foresees the acquisition of microclimatic data in Heddal and Ringebu stave churches for ca. 24 months since March 2019. Parallel, the MOV Project plans to cover a period of 50 years. The first part however is for the period 2017-2026 monitoring a total of 35 medieval wood and stone-based buildings

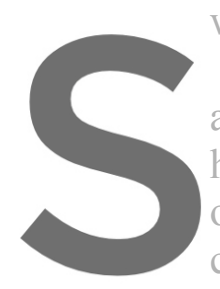

A stave church is a and vertical wooden had a raftered roof, obtained by the wodd from construction elements due to
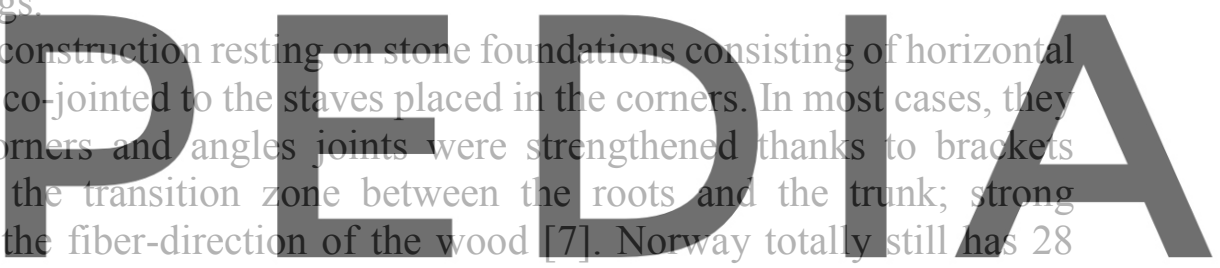

stave churches groupable into 4 main typologies of structures: i) simple; ii) Møre; iii) center

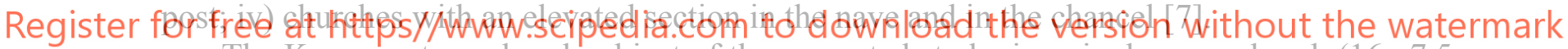

The Kvernes stave church, object of the presented study, is a single-nave church (16x 7.5

$\mathrm{m}$; capacity $=200$ people) dated back to the beginning of 1600. It is located in Møre and

Romsdal county on the west coast of Norway and is exposed to wind, high RH conditions through the year, and mild winters due to the proximity of the sea.

Internally the church displays a rich decorative apparatus being walls, the ceiling in the chancel, the nave, as well as the baptistery in the western end of the nave totally covered by distemper paintings dated back to 1630 s. Additionally a carved and painted polychrome epitaph dated to 1671 is positioned on northern wall, while a wooden painted altar carries an altarpiece with the corpus of a triptych (the wings are lost) referable to the late mediaeval period inserted into a carved and painted altarpiece in realized in 1695.

Contrarily to what happened in many historical churches in the 20th century, the Kvernes stave church never underwent the installation of a heating system due to the construction of a new second church in its proximity. For this reason, microclimatic fluctuations in the medieval church are basically referable to climatic external conditions, the performance of liturgical functions and to the presence or absence of visitors.

The research presented in this paper focuses on microclimatic data acquired through the installation of data loggers in 2011 during the Stave Church Preservation Programme for the 
monitoring of the Kvernes church over a 1-year period. Such data have been elaborated and represent the first real effort to scientifically investigate the internal microclimatic conditions achievable by monitoring campaigns in Stave Churches.

\section{MATERIALS AND METHODS}

Four Tinytag data loggers (Gemini Data Loggers Ltd, Chichester, UK) were placed in the east side of the Kvernes church as shown in Figure 1. The high of the four loggers was slightly different. Log named 1 and 2 were placed at a height of approx. 2 meters, while log named 4 and 5 were at about 3 meters above the floor.

$\mathrm{T}$ and RH data were collected from 20/06/2011 to 13/06/2012. Since logger 1-4 collected data every hour while log 5 every two hours, this last acquisition interval was selected in order to obtain comparable data series [8]. Outdoor data was collected from weather stations in proximity of the church site $\left(63.0^{\circ} \mathrm{N}, 7.7^{\circ} \mathrm{E}\right)$. Two weather stations were selected: i) Kristiansund Lufthavn $\left(63.1^{\circ} \mathrm{N}, 7.8^{\circ} \mathrm{E}\right.$, being associated to the Kristiansund Airport), recording from June 1970, to compare data acquired by loggers and ii) Kristiansund N, recording between March 1946 and December 1975, used to investigate a homogeneous climate normal period.

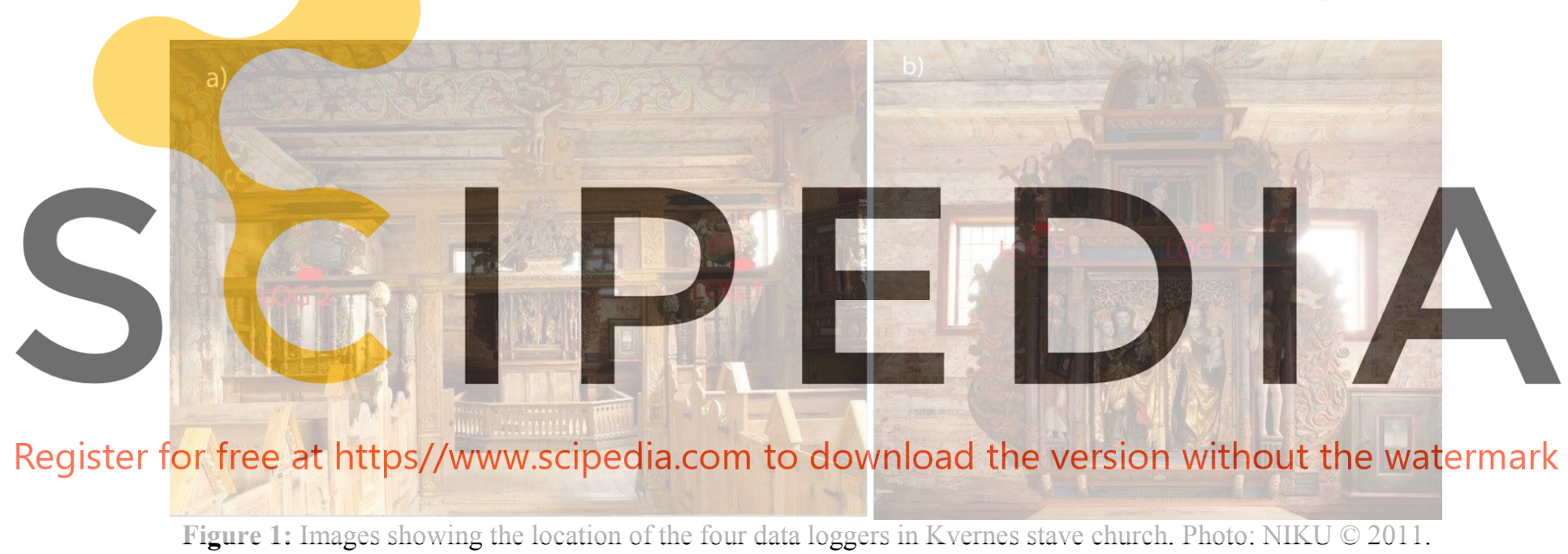

a) loggers 1 and 2 ; b) loggers 4 and 5 .

It is the average value of meteorological data over several decades and normally a 30 years period is considered, as required by the United Nations World Meteorological Organization (WMO), with the most used being the 1961-1990. However, in the case of weather stations in proximity of Kvernes, it has been not possible to find $\mathrm{RH}(\%)$ values over such normal period, for this reason a different time-window has been designated as reference period for our study. The utilized normal climate/ reference period is the 1957-1975 window, available from the weather station Kristiansund $\mathrm{N}$ and it allowed comparing the conditions of these 28 years with the monitored period 2011-2012 to assess the climate anomaly or variability during the monitoring campaign.

\section{DISCUSSION OF THE RESULTS}

The analysed 2011-2012 indoor data present the microclimatic situation of a typical unheated stave church in a coastal climate in Norway, which can be interestingly compared 
with available results from previous microclimatic monitoring campaign conducted in Medieval churches in Scandinavia.

\subsection{The comparison within Scandinavian Medieval Churches.}

Elaborations showed how information form LOG 1,2 and 4 resulted almost equivalent; consequently LOG 4 has been chosen as representative for the group of loggers. On the other hand, LOG 5 that was opportunely positioned in a location constantly hit by sun radiation, is representative of the radiation effect inside the church. Table 1 resumes results obtained in Kvernes and shows how the most significant differences among the two loggers concern RH values. Values collected by LOG5 are, in fact, generally lower, especially in summer (JJA). Obtained values can be compared with those more recently acquired (2017-2018) in the UNESCO World Heritage Site of the Urnes stave church (Table 2) and with those published by Napp et al [3] for Hangvar church, a Swedish medieval stone-based church in the northern part of the Gotland island in the Baltic sea (Table 3), and collected between 2010 and 2013. Values, seem to be comparable between the Kvernes and the Hangvar churches, even if the two structures have been realized using different materials. When comparing data with those acquired in Urnes, stronger variations emerge. In particular the average winter (DJF) temperature stays below $0^{\circ} \mathrm{C}$, probably because of the different climatic conditions in the area surrounding the Urnes church with respect to those of Kvernes located on the north west Norwegian sea-shore. Urnes is in the Sogn og Fjordane Region in the west, close to the shore of the innermost branch of a fiord.
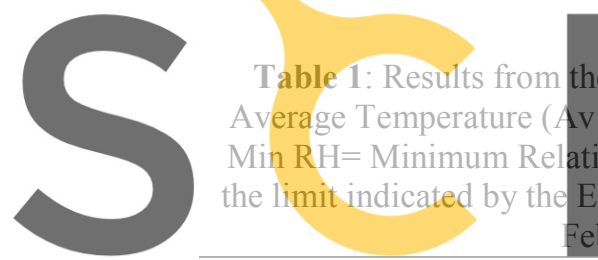

LOG4 Av T $\left({ }^{\circ} \mathrm{C}\right)$
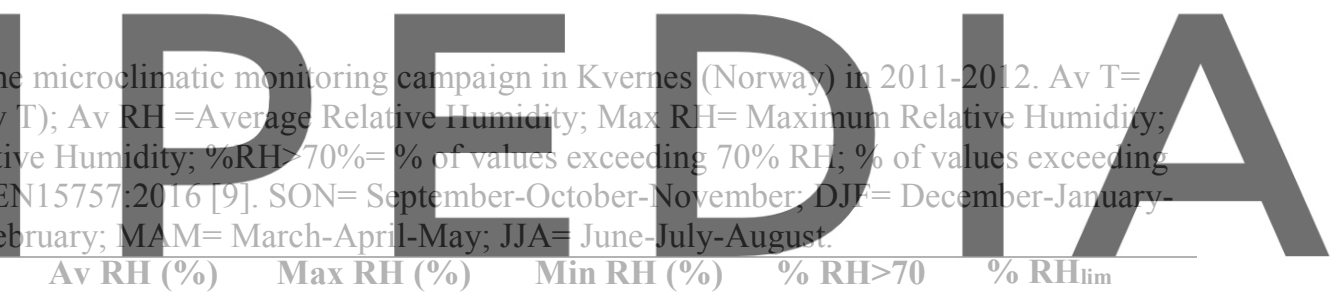

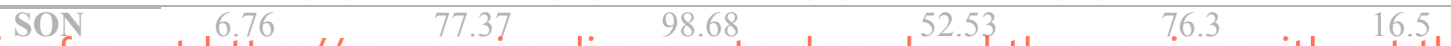

Register forjfree at https//www7.s. chpedia.com to downløad the version without the watermark

\begin{tabular}{lllllll} 
MAM & 10.06 & 80.47 & 92.39 & 48.15 & 93 & 5.1 \\
JJA & 14.48 & 80.85 & 92.66 & 52.28 & 95 & 1.7 \\
\hline LOG5 & & & & & & \\
\hline SON & 6.83 & 74.48 & 98.88 & 42.32 & 60 & 20 \\
DJF & 2.88 & 77.28 & 100 & 46.3 & 78 & 23 \\
MAM & 9.90 & 79.31 & 93.23 & 47.2 & 90 & 6 \\
JJA & 10.96 & 77.89 & 87.72 & 45.86 & 84 & 2 \\
\hline
\end{tabular}

Table 2: Results from the microclimatic monitoring campaign in Urnes (Norway) in 2017-2018. Av T= Average Temperature (Av T); Av RH =Average Relative Humidity; Max RH= Maximum Relative Humidity; Min RH= Minimum Relative Humidity; $\% \mathrm{RH}>70 \%=\%$ of values exceeding $70 \% \mathrm{RH} ; \%$ of values exceeding the limit indicated by the EN15757:2016 [9]. SON= September-October-November; DJF= December-January-February; $\mathrm{MAM}=$ March-April-May; JJA= June-July-August.

\begin{tabular}{lllllll}
\hline Urnes & Av T $\left({ }^{\circ} \mathbf{C}\right)$ & Av RH $(\%)$ & Max RH (\%) & Min RH (\%) & \% RH>70 & \% RH RH $_{\text {lim }}$ \\
\hline SON & 7.40 & 77.51 & 96.1 & 45.3 & 77 & 10 \\
DJF & -0.63 & 80.72 & 97.1 & 32.9 & 87 & 9.9 \\
MAM & 7.418 & 60.16 & 90 & 29.6 & 27 & 27 \\
JJA & 15.65 & 66.04 & 87.7 & 25.6 & 32 & 12 \\
\hline
\end{tabular}


Table 3: Results from the microclimatic monitoring campaign in Hangvar (Sweden) in 2010-2013 (adapted from [3]). Av T= Average Temperature (Av T); Av RH =Average Relative Humidity; Max RH= Maximum Relative Humidity; Min RH= Minimum Relative Humidity; $\%$ RH $>70 \%=\%$ of values exceeding $70 \%$ RH; $\%$ of values exceeding the limit indicated by the EN15757:2016 [9]. SON= September-October-November; DJF= DecemberJanuary-February; MAM= March-April-May; JJA= June-July-August.

\begin{tabular}{lllllll}
\hline Hangvar & Av T $\left({ }^{\circ} \mathbf{C}\right)$ & Av RH (\%) & Max RH (\%) & Min RH (\%) & \% RH $>70$ & $\%$ RH \\
\cline { 1 - 5 } SON & 11.3 & 77 & 90 & 63 & 89 & 19 \\
DJF & 3.3 & 75 & 96 & 54 & 78 & 0 \\
MAM & 6.8 & 80 & 90 & 63 & 100 & 0 \\
JJA & 9.6 & 81 & 96 & 63 & 98 & 31 \\
\hline
\end{tabular}

\subsection{Analysis of $T$ and RH variations in the Kyernes Stave Church.}

Elaborations of data collected in Kvernes are shown in Figure 2 in term of $\mathrm{T}$ and $\mathrm{RH}$ differences between indoors values at different daily time (i.e. at 8 a.m., 2 p.m. and 9 p.m.) and the outdoor minima, maxima and average values from the Kristiansund Lufthavn Station. A quite strong day-night variability is observable as well as differences due to the seasonal cycles caused by the synergistic effect of the building envelope, the use of the church (e.g. weekly religious offices and visitors presence in summer), and the distance between the church and the weather station location (ca. $10 \mathrm{~km}$ ). This effect changes during daytime along the year.

Morning: during all the year the indoor temperature at 8 a.m. (blue line, Figure 2) is warmer of ca. $2{ }^{\circ} \mathrm{C}$ respect to the outdoor daily minima. As already stated in Camuffo et al. 2016 [10], readings collected indoors at this time are not representative of the outdoor daily minima especially in Seandinavian countries where the time lag after sunrise changes quite a lot during the calendar therefore is representati equinoxes the sensor of ca. $2^{\circ} \mathrm{C}$ (Figure $2 \mathrm{~b}$, the maximum direct solar
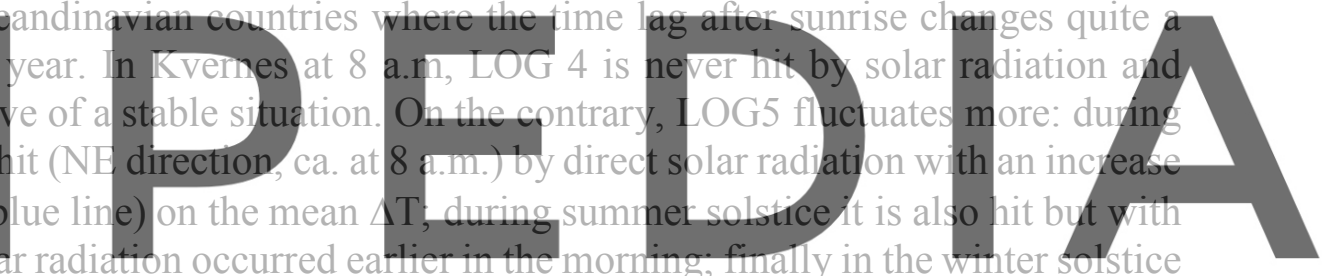

LOG5 is not reached by radiation.

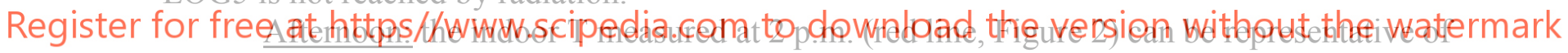
the outdoor daily maxima. During the whole year period, LOG 4 is hit by solar radiation: during summer solstice and equinoxes, the maxima of radiation impinging LOG4 (SW direction) occur respectively at ca. 3 p.m. and 2 p.m. while in winter solstice such maxima are extinguished some minutes earlier. For this reason, the indoor $\mathrm{T}$ is lower than outdoor maxima of ca. $2{ }^{\circ} \mathrm{C}$, fluctuating around or slightly exceeding this value from April to October (red line, Figure 2). LOG5, (NE corner direction) shows a similar situation, but being nor directly heated by solar radiation in the afternoon, it has a constant slightly lower indoor temperature.

Evening-Night: the $\Delta \mathrm{T}$ obtained by the indoor $\mathrm{T}$ - measured at 9 p.m.- minus the mean outdoor daily $\mathrm{T}$, is reported as black line in Figure 2. Black line fluctuates between $0{ }^{\circ} \mathrm{C}$ and 2 ${ }^{\circ} \mathrm{C}$ along the year, highlighting how the indoor reading at 9 p.m. is representative of the 24 hours outdoor daily mean [11]. This is especially true at equinoxes with a certain level of departure mainly during the summer solstice when LOG4, being hit for longer time in the afternoon and evening by solar radiation, records a departure of ca. $2^{\circ} \mathrm{C}$.

Similarly, also RH values detected indoors and outdoors and by the two loggers look quite different. An average situation, highlighted by the black line in Figure $2 \mathrm{c}$ and $2 \mathrm{~d}$ demonstrated that there is almost no difference between the RH measured at 9 p.m. inside 
Kvernes and the outdoor daily mean, except in summer, when due to the larger difference $\mathrm{T}$ and mixing ratio (MR) between the indoors and the outdoors, the RH values are lower inside of almost 7\%. Different are the situations induced by $\mathrm{T}$ and MR in the morning - that sees indoor RH fluctuating around a level 15\% higher than the minimum RH measured outdoors or in the afternoon, at 2 p.m. that sees indoor RH fluctuating around a level 15\% lower than the maxima RH measured outdoors, showing a slight damping of the fluctuations of RH compared with the external ones. The most evident difference between LOG5 and 4 being the T effect at 2 p.m. which induced a drop in the measured RH.

In order to deeper investigate the internal microclimatic conditions of the Kvernes stave church, a detailed analysis of the central months of each season was performed for LOG4 and LOG5. Elaborations proposed in Figures 3 and 4 show vertical windows individuating the dailylight durations as indicated by data available at [12], superimposed to T, RH and Mixing Ratio (MR) trends. Since the Kvernes church has never been heated, the indoor climate follows theoutdoor one except when people visit church (summer): in these cases, the presence of numerous visitors can strongly modify the indoor climate. Kvernes is, in fact, a museum church,housing special events and open for tourists (ca. 10000 visitors per year) in the summer season. While the impact of visitors is embedded in the microclimate reported in Figure 2 (period: end of June to mid-September), the observed environmental variations in Figures 3 and 4 cannot be imputed to these activities but rather at the standard condition of use of the churchwith its weekly religious service only. Internal data acquired by loggers can indeed be related to variations in T and RH of the external climate, which are shown in Figure 5. The analysis of outdoor temperature evolution indicate
period, as expectable, between the end of June and the en
additional maxima in October 2011 and balf of March 2012 .
$5 \mathrm{~b}$ green line) has highlighted two spells of drier period in
2012, just before the peak of temperature anomalies (F
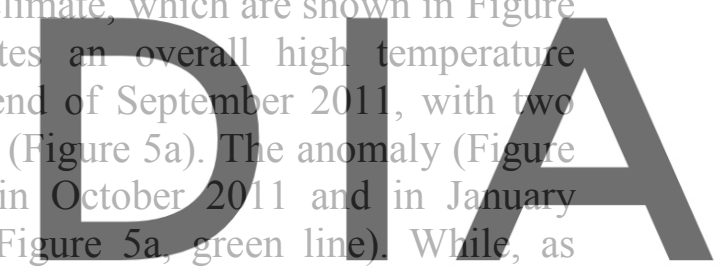

opposite a more humid period outside has been detected in March 2012 before the negative

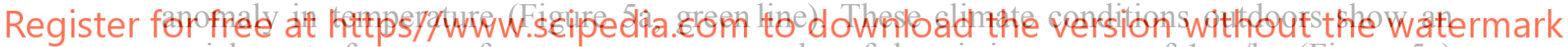
enrichment of grams of water vapor over onekg of dry air in average of $1 \mathrm{gr} / \mathrm{kg}$ (Figure $5 \mathrm{c}$ ) although spells of depletion of water vapor exist in conjunction with the drops in RH. Analyzing the microclimatic condition indoors for arepresentative week in summer, Figures 3 and 4 shows wider daily $\mathrm{T}$ and $\mathrm{RH}$ cycles with indoor $\mathrm{RH}$ changes ca. 10\% lower than outdoor conditions and following its seasonal cycle.

Daily $\mathrm{T}$ and RH minima and maxima fall within the daylight cycles. In this season, as reported in Table 3, the higher risk for the conservation of the decorated wooden elements in Kvernes is represented by the $\mathrm{RH}$ and $\mathrm{T}$ conditions which may trigger biological decay (i.e. $\mathrm{T}$ $>14^{\circ} \mathrm{C}$ and $\mathrm{RH}>70 \%$ ) that occur in the $95 \%$ of the time.

In the same season, Urnes stave church appears having lower risk of biological decay due to the generally lower indoor RH values (Table 2) [13]; while the appearance of fungi infestation in Hangvar with very high indoor RH may be naturally controlled in this season thanks to the still lower indoor T. However, biological decay- mould- is observed on the unpainted as well as the painted walls in Urnes, but not in Kvernes. In the representative week in autumn, indoor $\mathrm{RH}$ is usually higher than outdoor ones, the daily $\mathrm{T}$ and $\mathrm{RH}$ cycle is less evident (more evident from LOG4 readings than LOG5), in such microclimatic conditions in Kvernes, a certain risk of RH-induced mechanical decay can be recorded i.e. when indoor RH variability exceeds the safe limit of the target range of RH fluctuation, as defined by the EN15757:2010 [9] standard, 
and determined as the $7^{\text {th }}$ and $93^{\text {rd }}$ percentile of the fluctuations recorded in the monitoring period respect to the moving average [9] (Table 1).
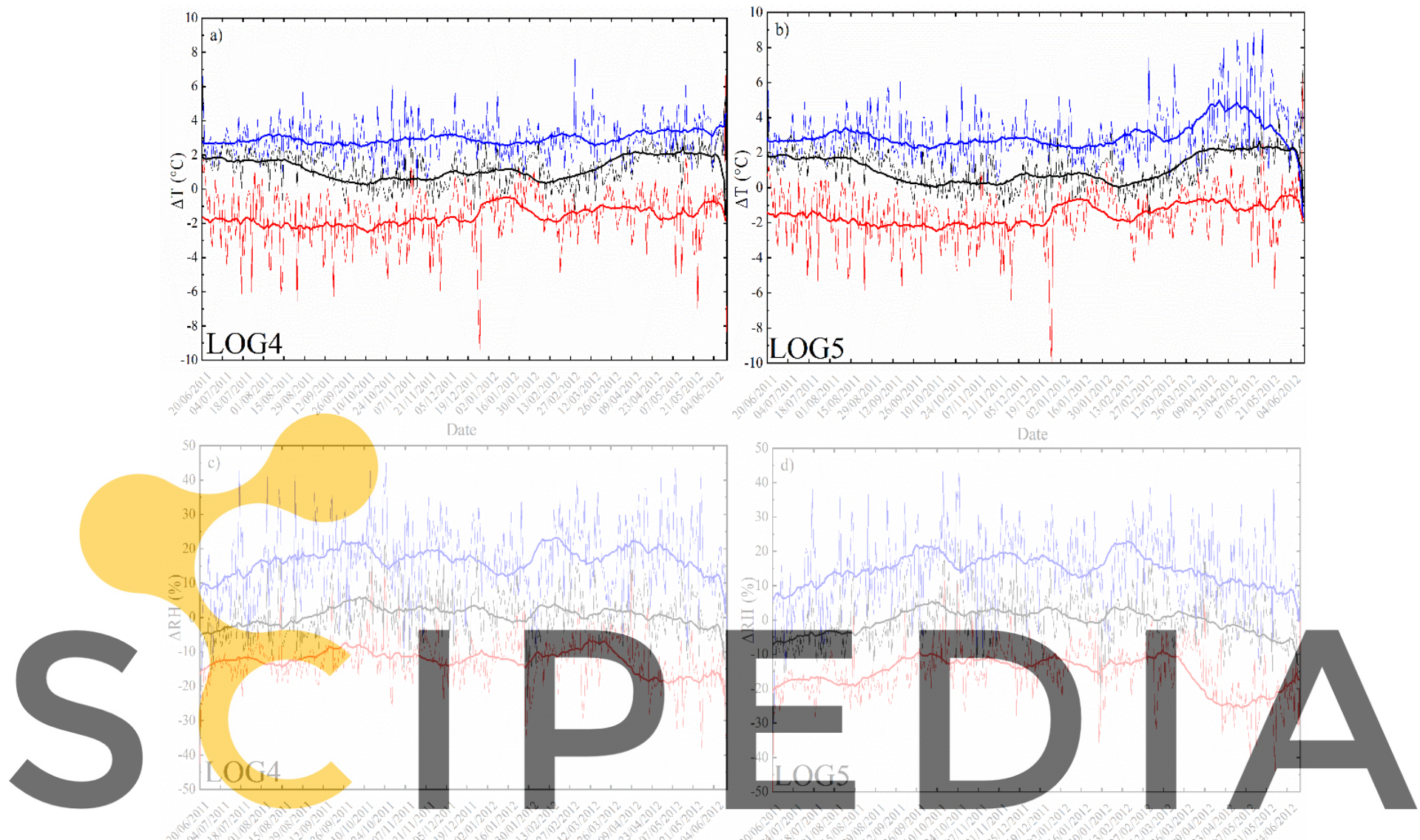

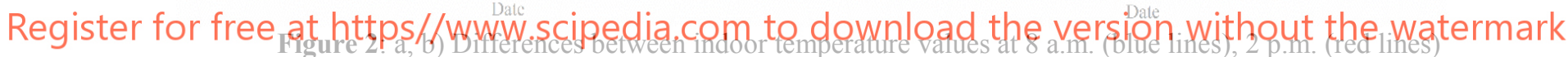

and 9 p.m (black lines) measured by LOG4 and 5 and the outdoor daily minima, maxima and mean values as

measured at the Kristiansund Lufth. Station. Thicker lines represent running averages of every series of data. c,

d) Differences between indoor Relative Humidity values measured at 8 a.m. (blue lines), 2 p.m. (red lines) and 9 p.m (black lines) by LOG4 and 5 and the outdoor minima, maxima and mean values measured at the

Kristiansund Lufth. Station. Thicker lines represent running averages of every series of data.

More in detail, the 7 th or 93 rd percentiles are obtained by ordering the fluctuations from the lowest negative value to the highest positive one and selecting the values below which 7 th or 93rd percent of observations are found, respectively. In this way $14 \%$ of the largest, most risky fluctuations are excluded, the cuts being equally applied to peaks and drops in $\mathrm{RH}$, yielding excessively moist or dry environments. In Kvernes, such risk of mechanical decay is at its maximum in winter when it can be further exacerbated by T-induced mechanical decay conditions of the winter season in Scandinavian countries last for longer time, often the spring due to freezing/thawing cycles. In a representative week in winter the daily $\mathrm{T}$ and $\mathrm{RH}$ cycle is smoothed out and the indoor RH becomes comparable with the outdoor ones. As the climatic season (MAM) resembles the winter in term of indoor microclimatic conditions. This is evident in the Urnes stave church (Table 2) that shows the higher risk of RH-induced mechanical decay 

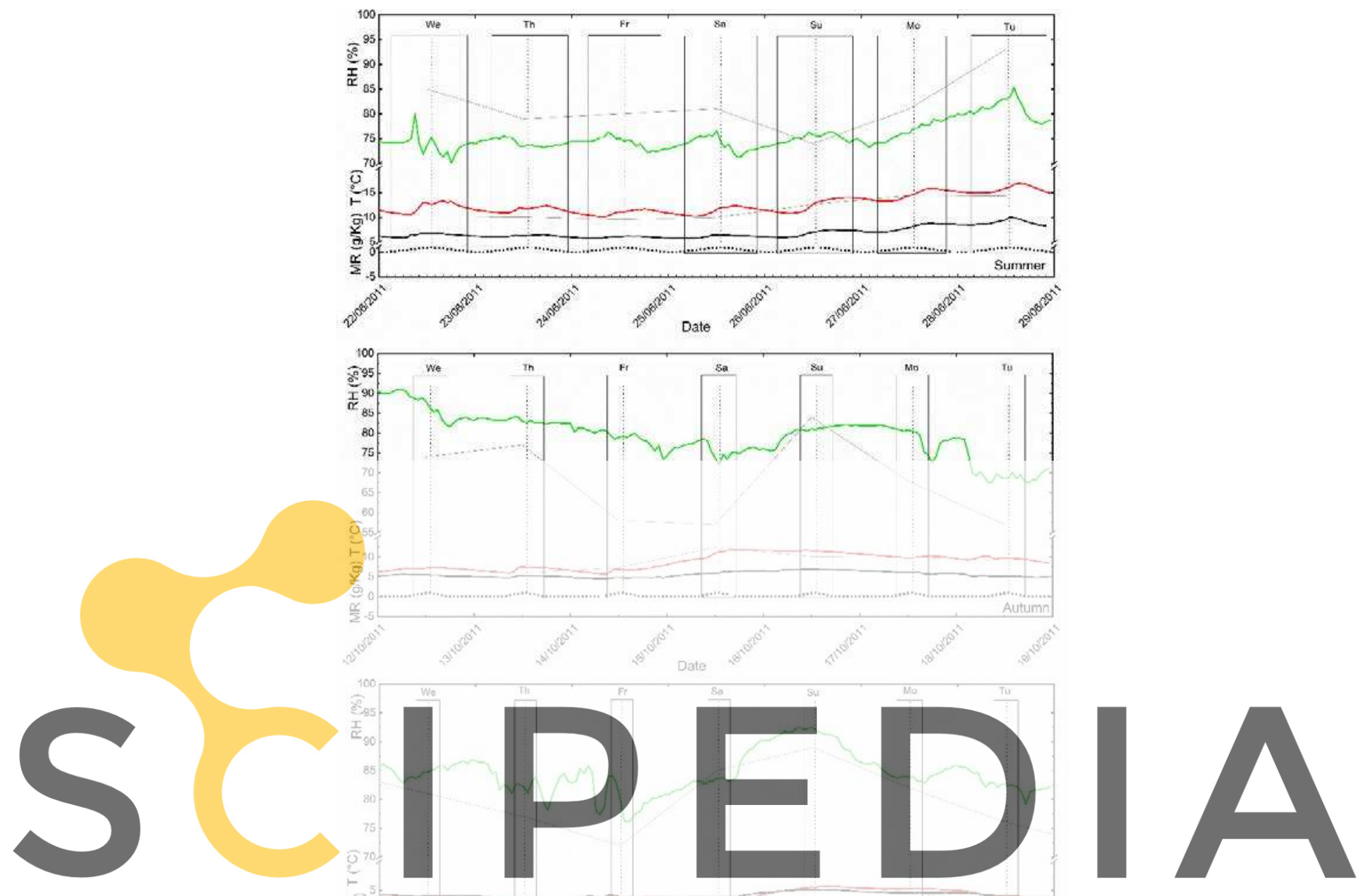

Register for free at https//www.scipedia.com to download the version without the watermark

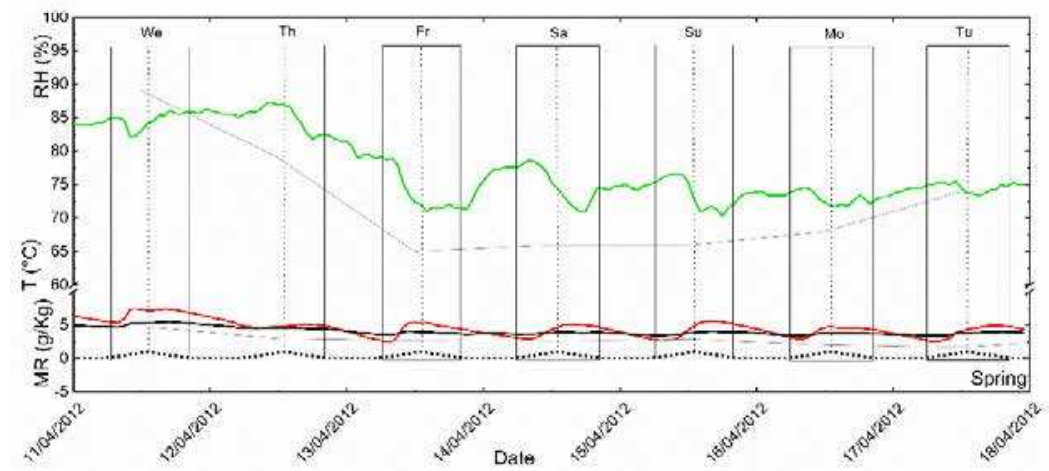

Figure 3: Indoor RH (\%)-green line, $\mathrm{T}\left({ }^{\circ} \mathrm{C}\right)$ - red line, $\mathrm{MR}(\mathrm{g} / \mathrm{Kg})$-black line values for a representative week in four seasons as measured by LOG 4. a) Summer 22/06/2011 and 28/06/2011; b) Autumn 12/10/2011 and 18/10/2011; Winter c) 11/01/2012 and 17/01/2012; d) Spring 11/04/2012 and 17/04/2012. The grey line refers to outdoor RH values collected by the Kristiansund Lufthavn meteorological station. 

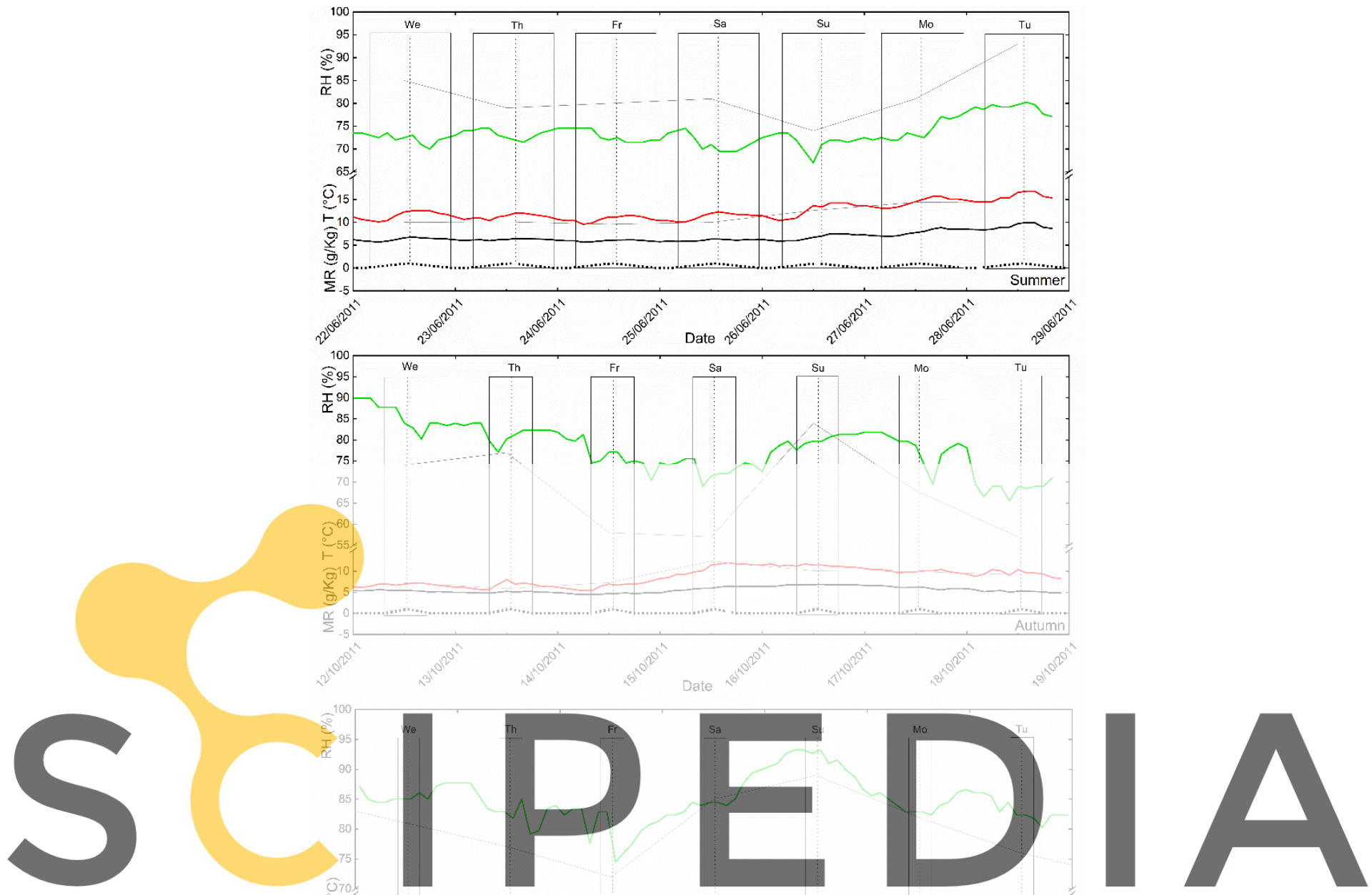

Register for free at httops//www:scipedia:com to download the version without the watermark

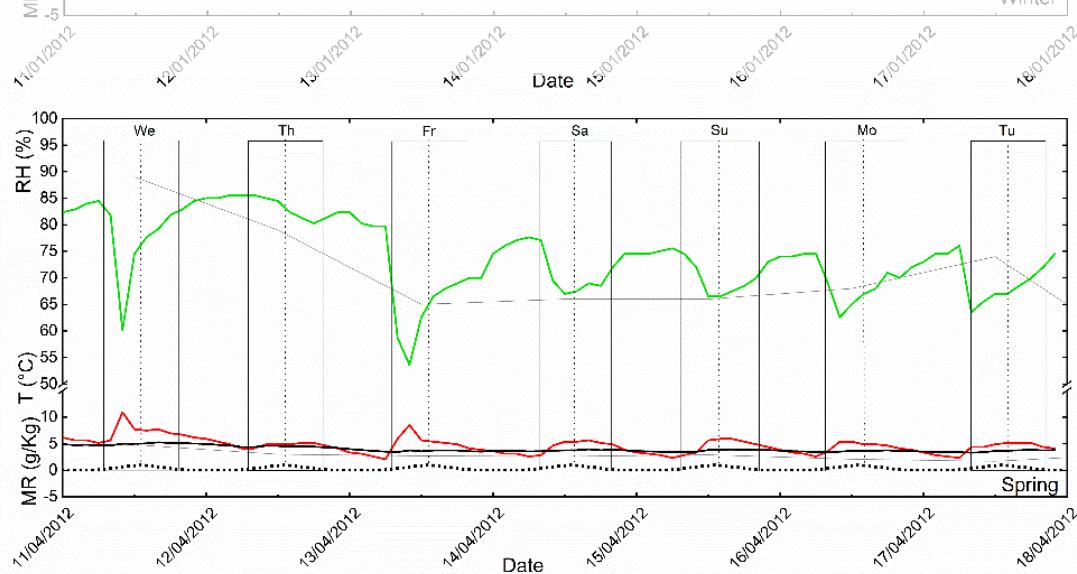

Figure 4: Indoor RH (\%)-green line, T $\left({ }^{\circ} \mathrm{C}\right)$ - red line, MR $(\mathrm{g} / \mathrm{Kg})$-black line values for a representative week in four seasons as measured by LOG 5. a) Summer 22/06/2011 and 28/06/2011; b) Autumn 12/10/2011 and 18/10/2011; Winter c) 11/01/2012 and 17/01/2012; d) Spring 11/04/2012 and 17/04/2012. The grey line refers to outdoor RH values collected by the Kristiansund lufthavn meteorological station. 

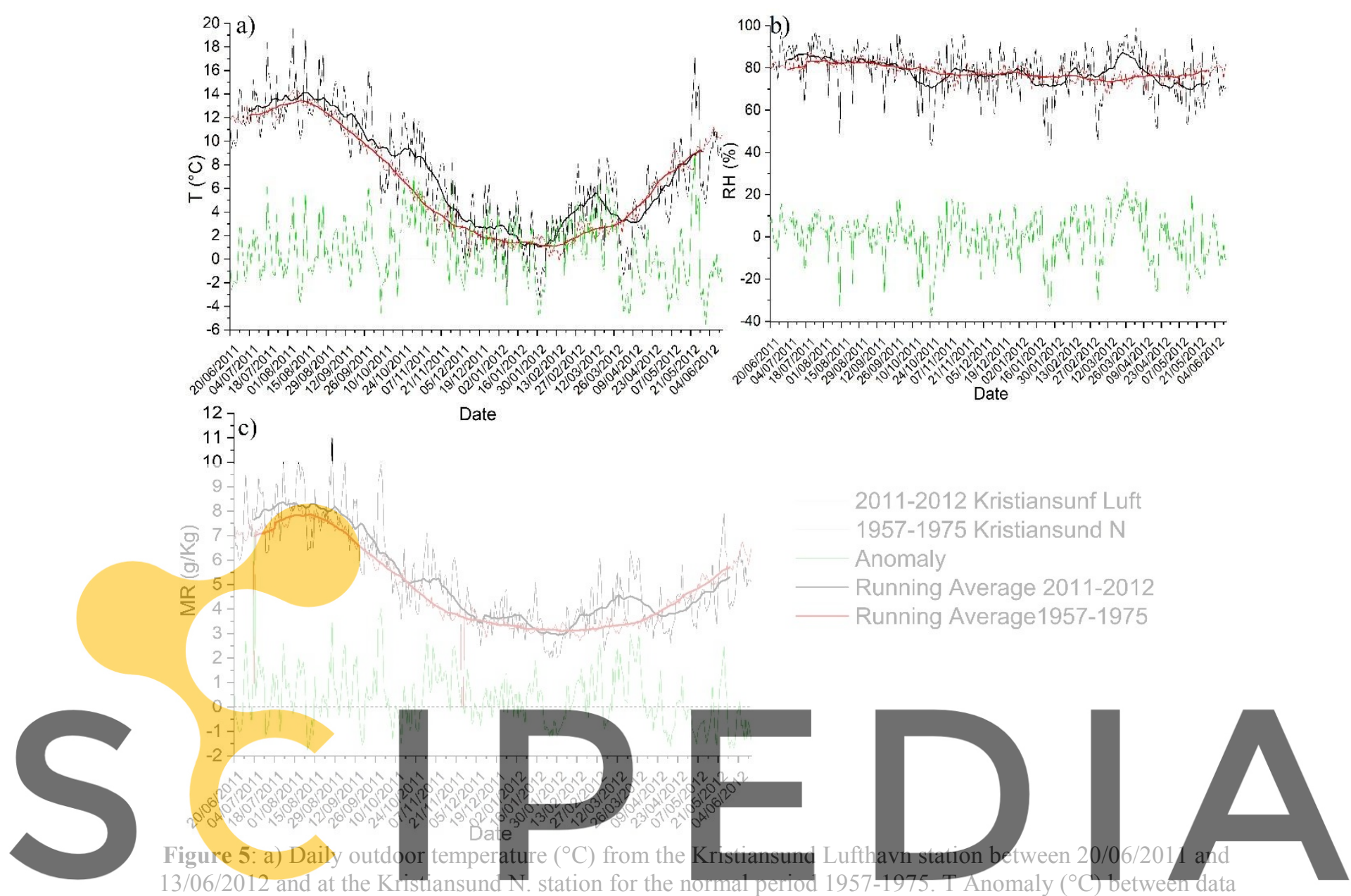

recorded in 2011-2012 and in 1957-1975. b) Daily outdoor Relative Humidity (\%) from the Kristiansund

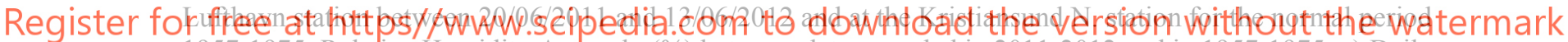
1957-1975. Relative Humidity Anomaly (\%) between data recorded in 2011-2012 and in 1957-1975; c) Daily outdoor Mixing Ratio (g/Kg) from the Kristiansund Lufthavn station between 20/06/2011 and 13/06/2012 and at the Kristiansund N. station for the normal period 1957-1975. Mixing Ratio Anomaly (g/Kg) between the data recorded in 2011-2012 and in1957-1975.

in this period, while Hangvar medieval stone church may encounter higher risk of mould infestation or condensation (Table 3).

\section{CONCLUSIONS}

The SyMBoL project is currently carrying out long-term (more than 2 years) monitoring campaigns in two stave churches in different climatic sites and under different in-use conditions (Heddal and Ringebu) to improve understanding of the "historic climate" [9]. Being most of existing data on microclimatic conditions in Scandinavian Medieval churches still unpublished at international level, this contribution was aimed on elaborating and presenting all the available data (i.e. with not restricted access) obtained by the monitoring campaigns conducted inside the Kvernes (Norway) Stave Church in 2011-2012. Being the church still unheated, variations in term of T, RH and MR are completely imputable to external climate modifications or to the presence of visitors in the summer opening and for special religious services. The effect of the 
church geographical position on its internal microclimate was assessed by comparison with data available from Urnes, located in a more internal area, not so affected by the sea influence (the Golf stream). Furthermore, the detailed analysis of indoor and outdoor conditions evidenced the relevance in loggers positioning in order to obtain complementary information permitting to depict a complete picture of the site internal conditions.

This study will be very beneficial as knowledge background for the MOV research project in Norway that, beside SyMBoL, is a long-term monitoring (planned for 50 years) project which aims to collect indoor and outdoor data on a similar category of historical buildings over a period of time comparable with that of climate norm.

The microclimatic analysis of the presented study highlights similarities in indoor climate conditions in unheated stave churches - located in different regions in Norway - and in a medieval stone church in Sweden. Such natural condition which the unheated church gives, may be ideal for the preservation of the distemper paints as these artworks remained in quite good conditions over centuries up to nowadays. In addition, the comparison with a stone-based medieval church located in a similar climate indicated no substantial differences within the two structures. This constitutes an additional important information for heritage managers and church owners, often dealing with the identification of risks situations and discrimination among the possible typologies of decay. The presented paper also provides reliable information for supporting risk management and climate change adaptation plans for the preservation of Medieval churches in Scandinavian countries because it makes available the actual or recent past or the zero level.

Funding: This study was funded by the Norwegian Research Council within the framework of the "SyMBoL - Sustainable Management of Heritage Building in a Long-term Perspective" Project (Project No. 274749). The authors are grateful to Else Marie Bae for her kind support during the monitoring campaign and to Kjersti Marie Ellewsen for sharing the data of her Master-thesis on the monitoring campaign conducted in Urnes Stave Church. The authors declare no conflict of interest.

\section{References}

[1] Cultural Heritage Act of June 9, 1978.

https://www.regjeringen.no/no/dokumenter/kulturminneloven/id173106/ (accessed on 08/01/2020)

[2]Bylund Melin, C. Wooden objects in historic buildings: Effects of dynamic relative humidity and temperature. $\mathrm{PhD}$ thesis. Department of Conservation; Göteborgs universitet. Naturvetenskapliga fakulteten, 2017.

[3]Napp,M., Wessberg, M., Kalamees, T., Brostrom, T. Adaptive ventilation for climate control in a medieval church in cold climate, Int. J. Vent. (2016) 15: 1-14.

[4] Olstad, T.M. Mediaeval wooden churches in a cold climate-parish churches or museums? Stud. Conserv. (1994) 39: 99-103.

[5]Lasyk, Ł., Łukomski, M., Olstad, T. M., Haugen, A. Digital speckle pattern interferometry for the condition surveys of painted wood: Monitoring the altarpiece in the church in Hedalen, Norway, J. Cult. Herit. (2012) 13S: S102-S108. 
[6]Lehne, M., Mantellato, S., Aguilar Sanchez, A. M., Caruso, F. Conservation issues and chemical study of the causes of alteration of a part of the Stave Church in Hopperstad (Norway), Herit. Sci. (2019) 7:80.

[7]Anker, L. What is a Stave Church. In: K. Bakken (Ed): Preserving the Stave Churches, Craftsmanship and Research, Print Best OU, Estonia, (2016), pp.17-22.

[8]Olstad, T. M. Klimaregistreringer i Kvernes stavkirke 2011-2012. Averøy kommune, Averøya. NIKU Report 24/2013. Unpublished. 2013.

[9]EN 15757:2010. Conservation of Cultural Property - Specifications for Temperature and Relative Humidity to Limit Climate-Induced Mechanical Damage in Organic Hygroscopic Materials, European Committee for Standardization, Brussels.

[10] Camuffo, D., della Valle, A., Bertolin C., Santorelli, E. The Stancari air thermometer and the 1715-1737 record in Bologna, Italy. Climatic Change (2016) 139: 623-636.

[11] Camuffo, D., della Valle, A., Bertolin, C., Santorelli, E. Temperature observations in Bologna, Italy, from 1715 to 1815: a comparison with other contemporary series and an overview of three centuries of changing climate. Climatic Change (2017) 142: 7-22.

[12]http://sharki.oslo.dnmi.no/portal/page?_pageid=73,39035,73_39049\&_dad=portal\&_sche ma=PORTA L (accessed 08/01/2020)

[13] Olstad, T. M., Ørnhøi, A. A., Kjølsen Jernæs, N., de Ferri, L., Freeman, A., Bertolin, C. Investigation, monitoring, risk assessment and decision making for the preservation of distemper paintings in Kvernes Stave Church, Climate, Submitted. 